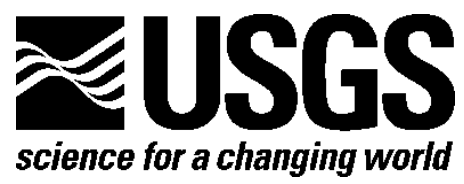

\title{
National Assessment of Shoreline Change-Summary Statistics for Updated Vector Shorelines and Associated Shoreline Change Data for the North Coast of Alaska, U.S.-Canadian Border to Icy Cape
}

By Ann E. Gibbs and Bruce M. Richmond

Open-File Report 2017-1107

U.S. Department of the Interior

U.S. Geological Survey 


\section{U.S. Department of the Interior \\ RYAN K. ZINKE, Secretary}

\section{U.S. Geological Survey \\ William H. Werkheiser, Acting Director}

U.S. Geological Survey, Reston, Virginia: 2017

For more information on the USGS—-the Federal source for science about the Earth, its natural and living resources, natural hazards, and the environment-visit https://www.usgs.gov/ or call 1-888-ASK-USGS (1-888-275-8747).

For an overview of USGS information products, including maps, imagery, and publications, visit https://store.usgs.gov.

Any use of trade, firm, or product names is for descriptive purposes only and does not imply endorsement by the U.S. Government.

Although this information product, for the most part, is in the public domain, it also may contain copyrighted materials as noted in the text. Permission to reproduce copyrighted items must be secured from the copyright owner.

Suggested citation:

Gibbs, A.E., and Richmond, B.M., 2017, National assessment of shoreline change-Summary statistics for updated vector shorelines and associated shoreline change data for the north coast of Alaska, U.S.Canadian border to Icy Cape: U.S. Geological Survey Open-File Report 2017-1107, 21 p., https://doi.org/10.3133/ofr20171107.

ISSN 2331-1258 (online) 


\section{Acknowledgments}

This report was made possible by the hard work and generous cooperation of many individuals. We thank the National Oceanic and Atmospheric Administration (NOAA) for providing scans of selected NOAA topographic sheets, BP Exploration (Alaska) and ConocoPhillips for digital historical shorelines and aerial imagery, and the U.S. Fish and Wildlife Service for aerial and satellite imagery. We also thank the U.S. Geological Survey's National Geospatial Program, Coastal and Marine Geology Program, and Alaska

Science Center as well as the U.S. Bureau of Land Management for light detection and ranging (lidar) data acquisition and processing. 


\section{Contents}

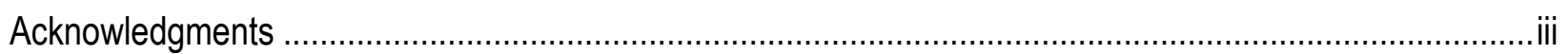

Abstract ………

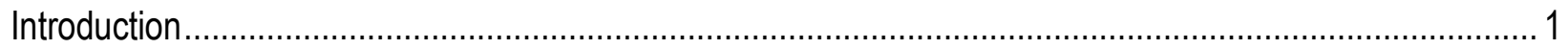

U.S Geological Survey National Assessment of Shoreline Change Project.......................................... 1

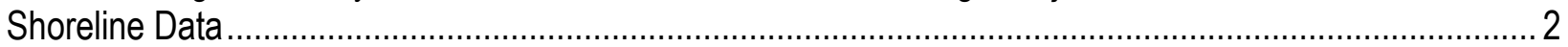

Calculation and Interpretation of Shoreline Change Rates ................................................................ 8

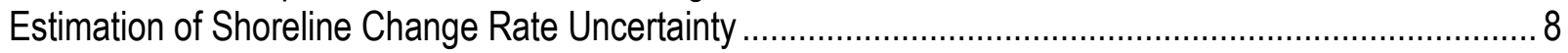

Estimation of Shoreline Position Uncertainty ............................................................................ 8

Estimation of Shoreline Change Rate Uncertainty at Individual Transects ........................................ 11

Regionally Averaged Rate Uncertainty ................................................................................... 11

Results from Analysis of Historical Shoreline Change ……............................................................ 19

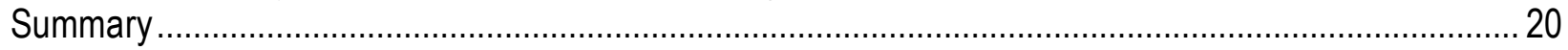

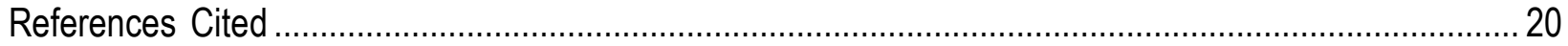

\section{Figures}

1. Map of the north coast of Alaska study area showing key geographic locations and the 10 regions discussed in this report................................................................................................ 2

2. Map of the north coast of Alaska study area showing location of gaps in shoreline data................. 4

3. Map of the north coast of Alaska study area showing data sources of shorelines used in this report and extent of the 4 data distribution subregions ....................................................................

4. Daily water level deviations from mean high water measured at the Prudhoe Bay tide gauge during light detection and ranging elevation data acquisition............................................................. 11

\section{Tables}

1. Providers and original sources of historical shoreline data for the north coast of Alaska..................5

2. Shorelines used to calculate change rates by coastal segment. ............................................... 5

3. Measurement uncertainties associated with all datasets........................................................ 9

4. Daily water level deviation from mean high water measured at the Prudhoe Bay tide gauge and calculated change in shoreline position............................................................................. 10

5. Summary of average shoreline change rates, average rate uncertainties, and percentage of transects eroding for the study area and each region relative to shoreline type........................... 13

6. Long- and short-term maximum shoreline change rates for each region....................................... 17 


\section{Conversion Factors}

\begin{tabular}{|c|c|c|}
\hline Multiply & By & To obtain \\
\hline \multicolumn{3}{|c|}{ Length } \\
\hline centimeter $(\mathrm{cm})$ & 0.3937 & inch (in.) \\
\hline meter $(\mathrm{m})$ & 3.281 & foot $(\mathrm{ft})$ \\
\hline meter (m) & 1.094 & yard (yd) \\
\hline kilometer $(\mathrm{km})$ & 0.6214 & mile (mi) \\
\hline kilometer $(\mathrm{km})$ & 0.5400 & mile, nautical (nmi) \\
\hline \multicolumn{3}{|c|}{ Flow rate } \\
\hline meter per year $(\mathrm{m} / \mathrm{yr})$ & 3.281 & foot per year ft/yr) \\
\hline
\end{tabular}

\section{Datum}

All positional measurements were made in the Universal Transverse Mercator (UTM) coordinate system on the North American Datum of 1983 (NAD 83). Data provided with this report were reprojected to the geographic coordinate system (GCS) on the World Geodetic System of 1984 (WGS 84) using the WGS_1984_(ITRF00)_To_NAD_1983 transformation in Esri ArcGIS version 10.3 .

Elevation, as used in this report, refers to distance above sea level.

\section{Abbreviations}

$\begin{array}{ll}\text { AHAP } & \text { Alaska High Altitude Photography } \\ \text { aHWL } & \text { approximate mean high water line } \\ \text { ANWR } & \text { Arctic National Wildlife Refuge } \\ \text { DEM } & \text { digital elevation model } \\ \text { DOQQ } & \text { digital orthophotograph quarter quadrangle } \\ \text { DSAS } & \text { Digital Shoreline Analysis System } \\ \text { lidar } & \text { light detection and ranging } \\ \text { LWI } & \text { land-water interface } \\ \text { MHW } & \text { mean high water } \\ \text { NOAA } & \text { National Oceanic and Atmospheric Administration } \\ \text { NOS } & \text { National Ocean Service } \\ \text { NPR-A } & \text { National Petroleum Reserve, Alaska } \\ \text { T-sheet } & \text { topographic sheet } \\ \text { USGS } & \text { U.S. Geological Survey }\end{array}$




\title{
National Assessment of Shoreline Change-Summary Statistics for Updated Vector Shorelines and Associated Shoreline Change Data for the North Coast of Alaska, U.S.-Canadian Border to Icy Cape
}

\author{
By Ann E. Gibbs and Bruce M. Richmond
}

\begin{abstract}
Long-term rates of shoreline change for the north coast of Alaska, from the U.S.Canadian border to the Icy Cape region of northern Alaska, have been updated as part of the U.S. Geological Survey's National Assessment of Shoreline Change Project. Short-term shoreline change rates are reported for the first time. Additional shoreline position data were used to compute rates where the previous rate-of-change assessment only included two shoreline positions at a given location. The calculation of uncertainty associated with the long-term average rates has also been updated to match refined methods used in other study regions of the National Assessment of Shoreline Change Project. The average rates of this report have a reduced amount of uncertainty compared to those presented in the first assessment for this region.
\end{abstract}

\section{Introduction}

\section{U.S Geological Survey National Assessment of Shoreline Change Project}

Beaches are a dynamic interface between water and land and are frequently subjected to a range of natural hazards, which include flooding, storm effects, and coastal erosion. The U.S. Geological Survey (USGS) is conducting a national assessment of coastal change hazards across the Nation. One component of this research effort, the National Assessment of Shoreline Change Project, documents changes in shoreline position as a proxy for coastal change. Shoreline position is one of the most commonly monitored indicators of environmental change (Morton, 1996), and it is an easily understood feature marking the location of a beach through time.

A principal component of the USGS National Assessment of Shoreline Change has been to develop a consistent methodology for calculating shoreline change rates and reporting results that may be periodically updated when additional data or improved techniques are available. Results have been organized and presented by coastal regions and include analyses and descriptive reports for the U.S. Gulf of Mexico coast (Morton and others, 2004; Himmelstoss and others, 2017), the southeast Atlantic coast (Morton and Miller, 2005; Himmelstoss and others, 2017), the California sandy shorelines (Hapke and others, 2006) and California coastal cliffs (Hapke and Reid, 2007), the New England and mid-Atlantic coasts (Hapke and others, 
2011), parts of the Hawaiian coast (Fletcher and others, 2012), and the Pacific Northwest (Ruggiero and others, 2013).

This report is an update to the original north coast of Alaska data (Gibbs and Richmond, 2015; Gibbs and others, 2015) and includes revised rate-of-change calculations based on two additional shoreline positions and improved rate metrics (fig. 1). The Alaska shoreline data differ from shoreline data in previously published USGS reports as follows:

- 1980s, 2000s, and 2010s era shorelines in this study represent a visually derived landwater interface position versus an elevation-based or tidal datum referenced shoreline position.

- Both exposed open-ocean and sheltered mainland-lagoon shorelines and rates of change are included in this study, compared to other locations where only exposed open-ocean sandy shorelines or bluff edges were evaluated.

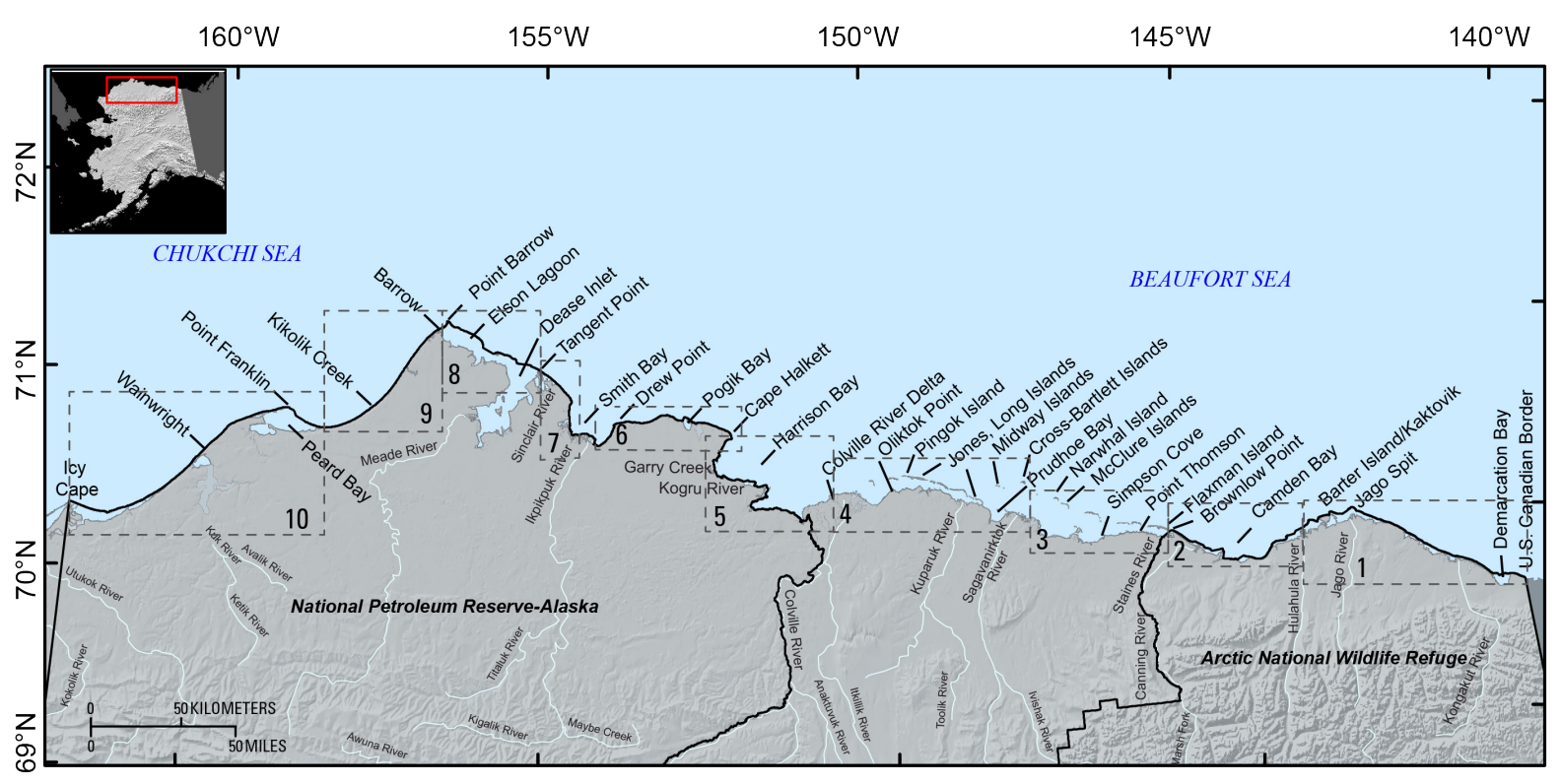

Figure 1. Shaded-relief map of the north coast of Alaska study area showing key geographic locations and the 10 regions discussed in this report. Shaded relief from U.S. Geological Survey 300-meter digital elevation model.

\section{Shoreline Data}

The USGS National Assessment of Shoreline Change analysis for the north coast of Alaska incorporates shoreline positions from a variety of data sources covering a range of dates (tables 1 and 2, fig. 3). Data from the previously published assessment included data for 2 specific time periods, circa 1940s and circa 2000s. This update includes data from 2 additional time periods, circa 1980 s and circa 2010 s.

The shoreline reference features, or shoreline proxy, mapped in this study were the "approximate mean high water line" (aHWL), as defined and mapped from topographic maps (1940s era T-sheets), and the instantaneous land-water interface, as interpreted on or mapped from 1980s and 2000s era photography, satellite imagery, and vector shorelines. Shorelines from the 2010s era were mapped as the instantaneous land-water interface, as identified on shaded- 
relief and slope maps derived from light detection and ranging (lidar) elevation data. Where no beach was identifiable in the imagery, the marsh vegetation or bluff edge and water interface was digitized. The land-water interface proxy for the 1980s and 2000s era imagery was generally well defined except where obscured by clouds, shadows, waves, or ice. The land-water interface for the lidar elevation model was generally well defined except in areas of low-lying topography. Shorelines were not digitized for highly variable deltaic regions and for intertidal mudflats because of large uncertainties identifying waterline intersections on gently sloping shorelines.

The land-water interface is not an ideal feature to use as a shoreline proxy because of the potentially wide variations in the horizontal position of the shoreline due to fluctuating water levels, which is especially pronounced in gently sloping environments. It was determined to be an acceptable proxy for this study, however, because of the low tidal range in the region (21 centimeters [0.7 feet] diurnal range; NOAA, 2016) and the fact that common proxies for high water lines (for example, beach wrack, wet/dry line, toe or berm of the beach) were difficult to delineate in the imagery used in this study owing to a number of factors, including narrow beaches, low contrast of beach sediment, low sun angles, and (or) a lack of debris material. Uncertainties associated with using the instantaneous land-water interface are included in the uncertainty analysis below.

Shorelines for the 1980s era were not available for a number of barrier islands along the central Beaufort Sea coast (McClure Islands, Narwhal Island, Cross-Bartlett Islands, Midway Islands, and the western portion of Pingok Island) and in western Harrison Bay between the Kogru River and Garry Creek (figs. 1 and 2). In these locations, no short-term shoreline change rates were calculated. Imagery for the 2000s era were not available for the east Chukchi Sea coast between Kikolik Creek and Icy Cape and a 2000s era shoreline was not delineated directly west of Brownlow Point due to the presence of snow and ice in the imagery. Shorelines for the 2010s era were not delineated near the Sinclair River east of Dease Inlet (figs. 1 and 2). Additional information regarding shoreline compilation methods and measurement uncertainties are available in Gibbs and Richmond (2015).

The shoreline change results and products prepared by the USGS are not intended for detailed site-specific analysis of shoreline movement, nor are they intended to replace any official sources of shoreline change information identified by local or State government agencies or other Federal entities for regulatory uses. Rates of shoreline change presented in this report represent shoreline movement under past conditions. The results are not intended for predicting future shoreline positions or future rates of shoreline change. Rates of shoreline change published in this report are for the purpose of a regional characterization of shoreline behavior through time. Individual measurement transects for the north coast of Alaska from the U.S.Canadian border to Icy Cape (Gibbs and others, 2017), as well as other open-ocean shoreline regions along the U.S. coast, can be viewed in the USGS Coastal Change Hazards Portal (https://marine.usgs.gov/coastalchangehazardsportal). 


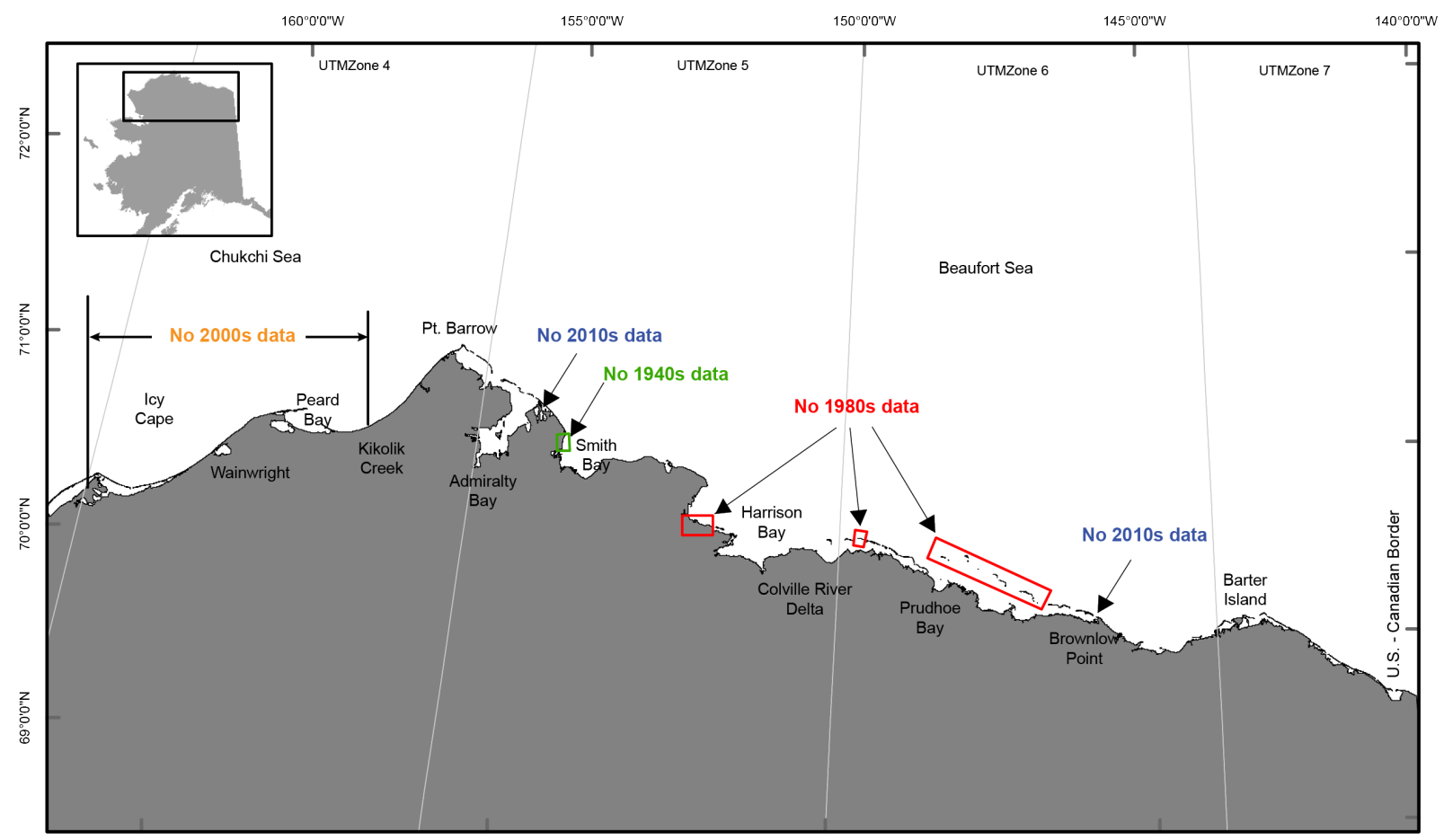

Figure 2. Map of the north coast of Alaska study area showing location of gaps in shoreline data. See figure 1 for additional geographic names. Map base from Alaska Department of Natural Resources, 1:63,360-scale digital coastline data, 1998. 
Table 1. Providers and original sources of historical shoreline data for the north coast of Alaska.

[ANWR, Arctic National Wildlife Refuge; NOAA, National Oceanic and Atmospheric Administration; NPR-A, National Petroleum Reserve, Alaska; DEM, digital elevation model; lidar, light detection and ranging; km, kilometer]

\begin{tabular}{|c|c|c|}
\hline Organization & Original data source & Spatial coverage \\
\hline NOAA Coastal Services Center & $\begin{array}{l}\text { Scanned NOAA topographic sheets (1947, } \\
1949,1986)\end{array}$ & All regions \\
\hline U.S. Fish and Wildlife Service & $\begin{array}{l}\text { Orthorectified Alaska High Altitude } \\
\text { Photography }(1978,1979,1982,1985)\end{array}$ & All regions \\
\hline U.S. Fish and Wildlife Service & $\begin{array}{l}\text { Pan-sharpened multispectral QuickBird } \\
\text { satellite imagery (2003) }\end{array}$ & $\begin{array}{l}\text { ANWR coast; Staines River } \\
\text { to the U.S.-Canadian } \\
\text { border }\end{array}$ \\
\hline U.S. Geological Survey & $\begin{array}{l}\text { Color-infrared digital orthophotograph } \\
\text { quarter quadrangles }(2002,2005)\end{array}$ & $\begin{array}{l}\text { NPR-A; Kikolik Creek to } \\
\text { Colville River Delta }\end{array}$ \\
\hline ConocoPhillips & $\begin{array}{l}\text { Color-infrared digital orthophotographs } \\
\quad(2004,2006)\end{array}$ & $\begin{array}{l}\text { Colville River Delta to about } \\
9 \mathrm{~km} \text { east of Oliktok Point }\end{array}$ \\
\hline BP Exploration (Alaska) & $\begin{array}{l}\text { Color-infrared digital orthophotographs } \\
\quad(2006,2007)\end{array}$ & $\begin{array}{l}\text { about } 9 \mathrm{~km} \text { east of Oliktok } \\
\text { Point to about } 9 \mathrm{~km} \text { east of } \\
\text { Point Thomson }\end{array}$ \\
\hline BP Exploration (Alaska) & $\begin{array}{l}\text { Digitized vector shorelines from } \\
\text { planimetric maps }(1997,2001)\end{array}$ & $\begin{array}{l}\text { Offshore barrier islands from } \\
\text { Midway Islands to } \\
\text { Brownlow Point }\end{array}$ \\
\hline $\begin{array}{l}\text { Geographic Information Network of } \\
\text { Alaska }\end{array}$ & $\begin{array}{l}\text { Alaska Statewide Orthoimagery Mosaic, } \\
\text { SPOT5 satellite imagery }(2010,2011)\end{array}$ & $\begin{array}{c}\text { Peard Bay, Wainwright Inlet, } \\
\text { Simpson Cove, Brownlow } \\
\text { Point, Demarcation Bay }\end{array}$ \\
\hline U.S. Geological Survey & $\begin{array}{l}\text { Airborne lidar DEM }(2009,2010,2011, \\
\text { 2012) }\end{array}$ & All regions \\
\hline
\end{tabular}

Table 2. Shorelines used to calculate change rates by coastal segment.

[AHAP, Alaska High Altitude Photography; aHWL, approximate mean high water line; BP, BP Exploration (Alaska); COP, ConocoPhillips; DEM, digital elevation model; lidar, light detection and ranging; LWI, land-water interface; T-sheet, topographic sheet; USGS, U.S. Geological Survey]

\begin{tabular}{|c|c|c|c|}
\hline Region & Date $^{1}$ & Source & Type \\
\hline \multirow[t]{4}{*}{ (1) U.S.-Canadian Border to Hulahula River } & 1947 & T-sheet & aHWL \\
\hline & 1978,1979 & AHAP & LWI \\
\hline & 2003 & QuickBird & LWI \\
\hline & 2009,2010 & Lidar DEM & LWI \\
\hline \multirow[t]{4}{*}{ (2) Hulahula River to Staines River } & 1947 & T-sheet & aHWL \\
\hline & 1979 & AHAP & LWI \\
\hline & 2003 & QuickBird & LWI \\
\hline & 2009,2010 & Lidar DEM & LWI \\
\hline \multirow[t]{7}{*}{ (3) Staines River to Sagavanirktok River } & 1947 & T-sheet & aHWL \\
\hline & 1982 & AHAP & LWI \\
\hline & 2003 & QuickBird & LWI \\
\hline & 2006 & COP, BP aerial photograph & LWI \\
\hline & 1997 & BP aerial photograph & LWI \\
\hline & 2001 & BP aerial photograph & LWI \\
\hline & 2010 & Lidar DEM & LWI \\
\hline
\end{tabular}




\begin{tabular}{|c|c|c|c|}
\hline Region & Date $^{1}$ & Source & Type \\
\hline \multirow[t]{7}{*}{ (4) Sagavanirktok River to Colville River } & 1947 & T-sheet & aHWL \\
\hline & 1979, 1982 & AHAP & LWI \\
\hline & 1997 & BP aerial photograph & LWI \\
\hline & 2004 & COP, BP aerial photograph & LWI \\
\hline & 2006 & $\mathrm{COP}, \mathrm{BP}$ aerial photograph & LWI \\
\hline & 2007 & COP, BP aerial photograph & LWI \\
\hline & 2010 & Lidar DEM & LWI \\
\hline \multirow[t]{4}{*}{ (5) Colville River to Cape Halkett } & 1947 & T-sheet & aHWL \\
\hline & 1979 & AHAP & LWI \\
\hline & 2002 & USGS aerial photograph & LWI \\
\hline & 2010, 2011 & Lidar DEM & \\
\hline \multirow[t]{4}{*}{ (6) Cape Halkett to Ikpikpuk River } & 1947 & T-sheet & aHWL \\
\hline & 1979 & AHAP & LWI \\
\hline & 2002 & USGS aerial photograph & LWI \\
\hline & $2010-12$ & Lidar DEM & \\
\hline \multirow[t]{4}{*}{ (7) Smith Bay to Dease Inlet } & 1947 & T-sheet & aHWL \\
\hline & 1979 & AHAP & LWI \\
\hline & 2002 & USGS aerial photograph & LWI \\
\hline & $2010-12$ & Lidar DEM & LWI \\
\hline \multirow[t]{6}{*}{ (8) Dease Inlet to Point Barrow } & 1947 & T-sheet & aHWL \\
\hline & 1979 & AHAP & LWI \\
\hline & 1986 & T-sheet & aHWL \\
\hline & 2002 & USGS aerial photograph & LWI \\
\hline & 2005 & USGS aerial photograph & LWI \\
\hline & $2010-12$ & Lidar DEM & LWI \\
\hline \multirow[t]{4}{*}{ (9) Point Barrow to Peard Bay } & 1947 & T-sheet & aHWL \\
\hline & 1979 & AHAP & LWI \\
\hline & 2005 & USGS aerial photograph & LWI \\
\hline & 2010 & Lidar DEM & LWI \\
\hline \multirow[t]{5}{*}{ (10) Peard Bay to Icy Cape } & 1947 & T-sheet & aHWL \\
\hline & 1949 & T-sheet & aHWL \\
\hline & 1979, 1986 & AHAP & LWI \\
\hline & $2010-12$ & Lidar DEM & LWI \\
\hline & $2010-11$ & SPOT5 & LWI \\
\hline
\end{tabular}

${ }^{1}$ For details about dates of shoreline data used at specific locations within a region, refer to the shoreline data files available for download in the companion online data release (Gibbs and others, 2017). 

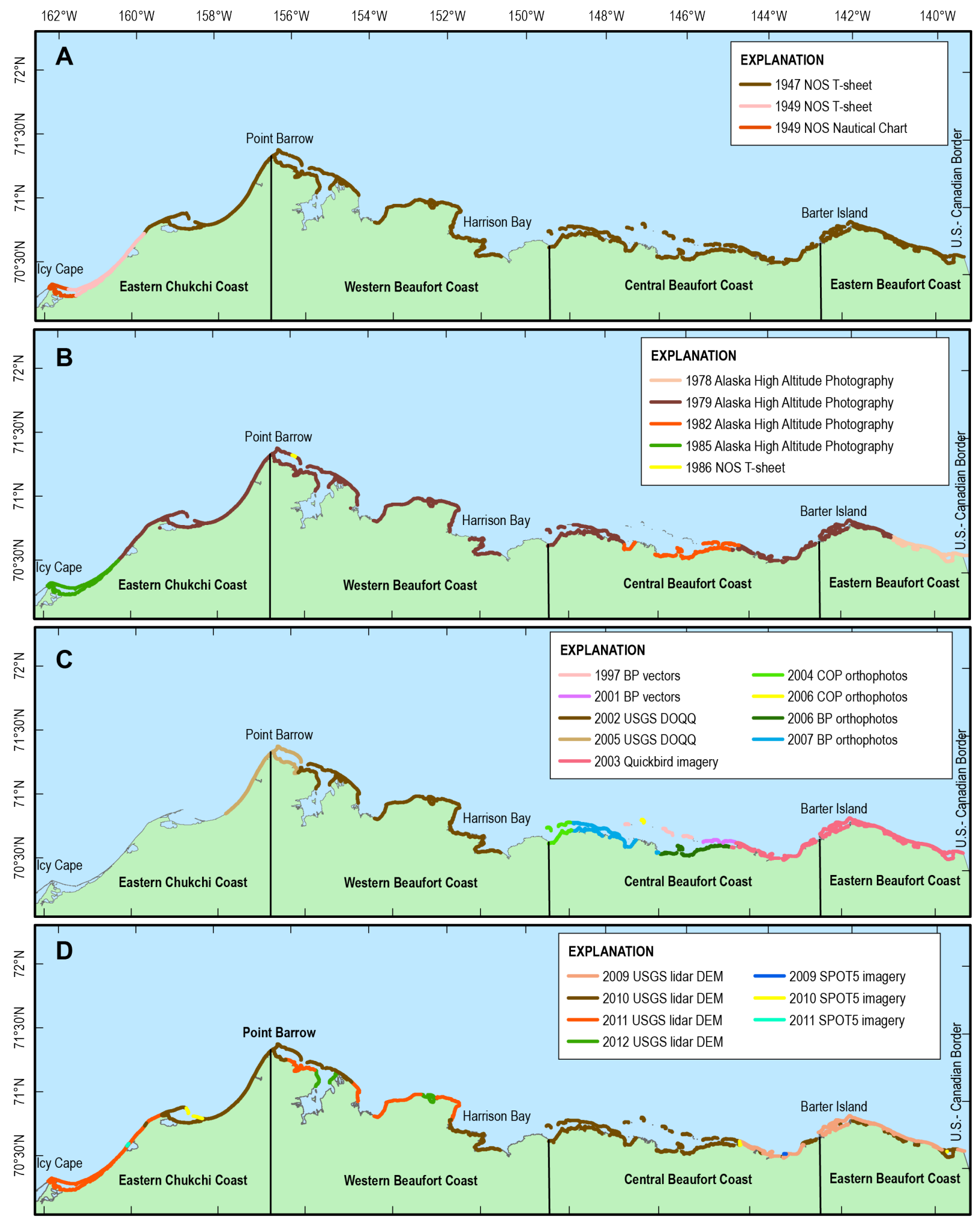

Figure 3. Map of the north coast of Alaska study area showing data sources of shorelines used in this report and extent of the 4 data distribution subregions. $A, 1940$ s era shorelines. $B, 1980$ s era shorelines. $C, 2000$ s era shorelines. $D, 2010$ s era shorelines. See figure 1 for additional geographic names. BP, BP Exploration (Alaska); COP, ConocoPhillips; DEM, digital elevation model; DOQQ, digital orthophotograph 
quarter quadrangle; lidar, light detection and ranging; NOS, National Ocean Service; T-sheet, topographic sheet. Map base from Alaska Department of Natural Resources, 1:63,360-scale digital coastline data, 1998.

\section{Calculation and Interpretation of Shoreline Change Rates}

Rates of long-term ( $>60$ years) and short-term $(<34$ years) shoreline change were calculated approximately every 50 meters alongshore using the linear regression and end-point rate calculation methods included in the Digital Shoreline Analysis System (DSAS), versions 4.2 and 4.3 (Thieler and others, 2009). Long-term rates of shoreline change, in meters per year, were calculated at each transect using a linear regression rate calculation between the 1940s, 1980s, 2000 s, and 2010s era shoreline positions. At some transect locations only 3 shoreline positions were available, however, the 1940s and 2010s shorelines were present at all transects and all rates were calculated using the linear regression method. Short-term rates of shoreline change, in meters per year, were calculated at each transect using a linear regression rate calculation between the 1980s, 2000s, and 2010s era shorelines. At transect locations where only 2 shoreline positions were available (1980s and 2010s; east Chukchi Sea coastlines), short-term rates of shoreline change were calculated at each transect using an end-point rate calculation.

The shoreline change rates and rate uncertainties at individual transect locations are available in the data release associated with this report (Gibbs and others, 2017).

\section{Estimation of Shoreline Change Rate Uncertainty}

Several sources of error affect the positional certainty of historical shoreline data and the uncertainties associated with the shoreline change rates calculated from them. A detailed methodology and discussion of uncertainties associated with the north coast of Alaska shoreline change assessment can be found in Gibbs and Richmond (2015).

\section{Estimation of Shoreline Position Uncertainty}

For each shoreline position, the total uncertainty is found as the square root of the sum of squares of the relevant uncertainty terms, based on an assumption that each term is random and independent of the others (Taylor, 1997). For shorelines derived for this study, the total shoreline position uncertainty $\left(U_{p}\right)$ at each transect $i$, is calculated following the method developed by Hapke and others $(2006,2011)$ :

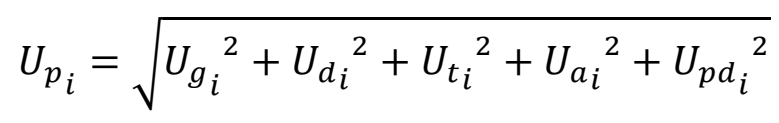

Individual uncertainty terms in equation 1 are defined in table 3 . Shoreline position uncertainties are included in the digital shoreline data files associated with this report (Gibbs and others, 2017). Measurement and total shoreline position uncertainties for all datasets used in this updated analysis are listed in table 3 as determined by equation 1 . Water level deviations from mean high water (MHW) measured at the Prudhoe Bay tide gauge (NOAA, 2016) that were used to estimate average horizontal position offsets for all data sets collected after 1990 (when the Prudhoe Bay gauge started recording) are listed in table 4 and shown graphically for the lidar elevation data acquisition windows (fig. 4). 
Table 3. Measurement uncertainties associated with all datasets.

[-, not applicable; NA, not available; AHAP, Alaska High Altitude Photography; BP, BP Exploration (Alaska); COP, ConocoPhillips; DOQQ, digital orthophotograph quarter quadrangle; lidar, light detection and ranging;

T-sheets, topographic sheets]

\begin{tabular}{|c|c|c|c|c|c|c|c|c|c|c|c|c|c|}
\hline $\begin{array}{c}\text { Measurement } \\
\text { Uncertainty (meters) }\end{array}$ & 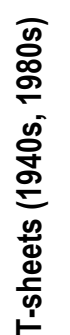 & 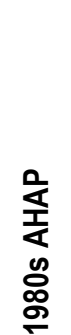 & 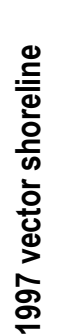 & 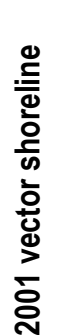 & 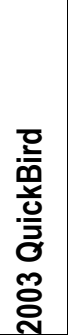 & 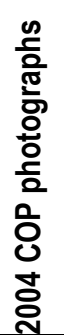 & $\begin{array}{l}\frac{n}{0} \\
\frac{0}{0} \\
\frac{5}{0} \\
\frac{0}{0} \\
\frac{0}{2} \\
0 \\
0 \\
0 \\
0 \\
0\end{array}$ & 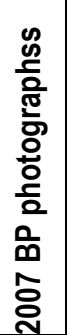 & 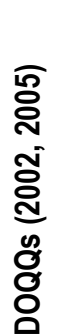 & 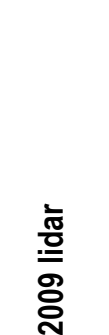 & $\begin{array}{l}\frac{i}{0} \\
\text { 음 } \\
\text { 윰 }\end{array}$ & 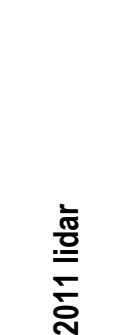 & 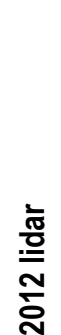 \\
\hline Georeferencing $\left(U_{g}\right)$ & 11 & 10 & - & - & - & - & - & - & - & - & - & - & - \\
\hline Digitizing $\left(U_{d}\right)$ & 5 & 3 & 1 & 1 & 1 & 1 & 1 & 1 & 5 & 6 & 6 & 6 & 6 \\
\hline T-sheet survey $\left(U_{t}\right)$ & 10 & - & - & - & - & - & - & - & - & - & - & - & - \\
\hline $\begin{array}{l}\text { Aerial/satellite } \\
\text { photograph }\left(U_{a}\right)\end{array}$ & - & - & 4 & 4 & 6 & 3 & 3 & 3 & 3 & - & - & - & - \\
\hline High water line $^{1}\left(U_{p d}\right)$ & - & $\mathrm{NA}$ & 4 & 0 & -1 & 4 & 3 & 1 & 1 & 5 to 6 & -5 to +8 & -1 to +5 & 6 \\
\hline $\begin{array}{l}\text { Total shoreline position } \\
\text { uncertainty }{ }^{2}\left(U_{p}\right)\end{array}$ & 16 & 10 & 6 & 4 & 6 & 5 & 4 & 3 & 6 & 8 to 9 & 6 to 10 & 6 to 8 & 8 \\
\hline
\end{tabular}

${ }^{1}$ Range of mean horizontal change for all surveys in a single year. See table 4 for individual values; water level data are not available prior to 1990 .

${ }^{2}$ Range of uncertainties for all days in a single year; absolute values are included in the transect data files. 
Table 4. Daily water level deviation from mean high water (MHW) measured at the Prudhoe Bay tide gauge and calculated change in shoreline position.

[BP, BP Exploration (Alaska); COP, ConocoPhillips; DOQQ, digital orthophotograph quarter quadrangle; lidar, light detection and ranging]

\begin{tabular}{|c|c|c|c|c|c|c|c|}
\hline \multirow[t]{2}{*}{ Data Source } & \multirow[t]{2}{*}{ Acquisition Date } & \multicolumn{3}{|c|}{$\begin{array}{l}\text { Water level deviation from MHW } \\
\text { (meters) }\end{array}$} & \multicolumn{3}{|c|}{$\begin{array}{c}\text { Horizontal change }{ }^{1} \\
\text { (meters) }\end{array}$} \\
\hline & & Maximum & Minimum & Mean & Maximum & Minimum & Mean \\
\hline 1997 vector & 24 July 1997 & 0.33 & 0.09 & 0.21 & 6.60 & 1.80 & 4.20 \\
\hline 2001 vector & 30 Aug. 2001 & 0.13 & -0.14 & 0.00 & 2.64 & -2.80 & -0.08 \\
\hline 2002 DOQQ & 16 July 2002 & 0.15 & -0.03 & 0.06 & 3.02 & -0.66 & 1.18 \\
\hline 2002 DOQQ & 17 July 2002 & 0.26 & -0.06 & 0.10 & 5.10 & -1.20 & 1.95 \\
\hline 2002 DOQQ & 18 July 2002 & 0.15 & -0.06 & 0.05 & 2.92 & -1.12 & 0.90 \\
\hline 2003 QuickBird & 29 Aug. 2003 & 0.07 & -0.19 & -0.06 & 1.38 & -3.82 & -1.22 \\
\hline $2004 \mathrm{COP}$ & 26 July 2004 & 0.23 & 0.20 & 0.22 & 4.64 & 4.04 & 4.34 \\
\hline 2005 DOQQs & 25 July 2005 & 0.05 & -0.19 & -0.07 & 0.94 & -3.84 & -1.45 \\
\hline $2006 \mathrm{BP}$ & 12 July 2006 & 0.02 & 0.01 & 0.01 & 0.32 & 0.22 & 0.27 \\
\hline $2006 \mathrm{BP}$ & 24 July 2006 & 0.11 & 0.09 & 0.10 & 2.16 & 1.70 & 1.93 \\
\hline $2006 \mathrm{BP}$ & 25 July 2006 & 0.24 & 0.22 & 0.23 & 4.76 & 4.48 & 4.62 \\
\hline $2007 \mathrm{BP}$ & 4 July 2007 & 0.13 & 0.01 & 0.07 & 2.54 & 0.22 & 1.38 \\
\hline 2009 lidar & 2 Sept. 2009 & 0.43 & 0.14 & 0.29 & 8.68 & 2.82 & 5.75 \\
\hline 2009 lidar & 3 Sept. 2009 & 0.52 & -0.04 & 0.24 & 10.32 & -0.78 & 4.77 \\
\hline 2009 lidar & 5 Sept. 2009 & 0.54 & 0.10 & 0.32 & 10.70 & 1.96 & 6.33 \\
\hline 2010 lidar & 8 July 2010 & -0.22 & -0.26 & -0.24 & -4.40 & -5.10 & -4.75 \\
\hline 2010 lidar & 16 July 2010 & 0.14 & -0.39 & -0.12 & 2.74 & -7.70 & -2.48 \\
\hline 2010 lidar & 24 July 2010 & 0.19 & -0.03 & 0.08 & 3.88 & -0.64 & 1.62 \\
\hline 2010 lidar & 25 July 2010 & 0.09 & -0.14 & -0.02 & 1.88 & -2.70 & -0.41 \\
\hline 2010 lidar & 26 July 2010 & 0.09 & -0.03 & 0.03 & 1.88 & -0.64 & 0.62 \\
\hline 2010 lidar & 27 July 2010 & 0.12 & -0.11 & 0.01 & 2.46 & -2.22 & 0.12 \\
\hline 2010 lidar & 28 July 2010 & 0.26 & 0.00 & 0.13 & 5.24 & -0.08 & 2.58 \\
\hline 2010 lidar & 2 Aug. 2010 & 0.56 & 0.05 & 0.30 & 11.10 & 0.92 & 6.01 \\
\hline 2010 lidar & 3 Aug. 2010 & 0.49 & 0.29 & 0.39 & 9.70 & 5.88 & 7.79 \\
\hline 2011 lidar & 28 July 2011 & 0.32 & 0.03 & 0.17 & 6.44 & 0.54 & 3.49 \\
\hline 2011 lidar & 6 Aug. 2011 & 0.08 & -0.14 & -0.03 & 1.68 & -2.88 & -0.60 \\
\hline 2011 lidar & 12 Sept. 2011 & 0.35 & 0.16 & 0.25 & 6.98 & 3.18 & 5.08 \\
\hline 2011 lidar & 13 Sept. 2011 & 0.38 & 0.12 & 0.25 & 7.50 & 2.32 & 4.91 \\
\hline 2012 lidar & 12 Aug. 2012 & 0.33 & 0.26 & 0.29 & 6.68 & 5.10 & 5.89 \\
\hline
\end{tabular}

${ }^{1}$ Horizontal change determined by multiplying the water level deviation by an assumed beach slope of 1:20. 


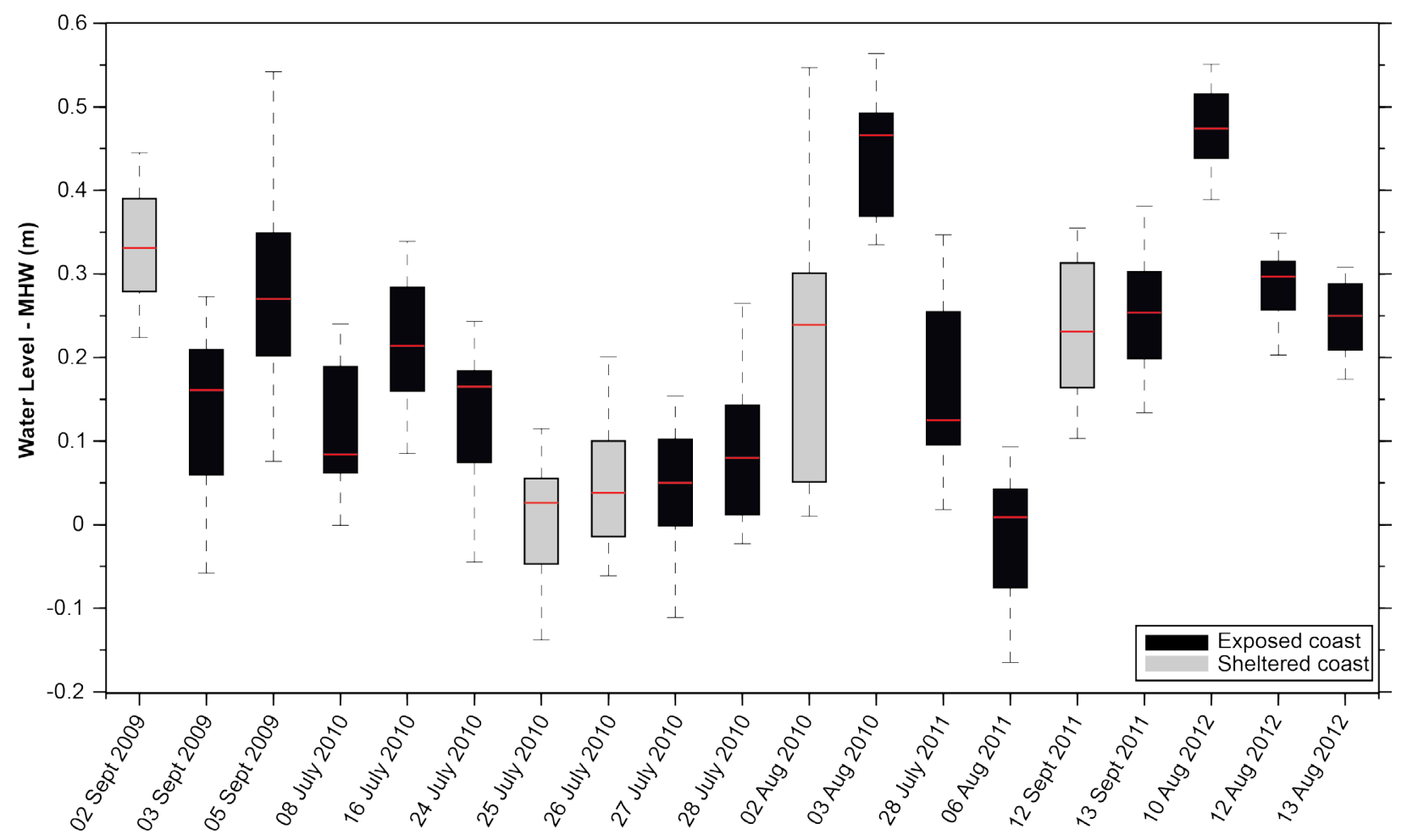

Figure 4. Daily water level deviations from mean high water (MHW) measured at the Prudhoe Bay tide gauge during light detection and ranging (lidar) elevation data acquisition. Water level deviation shown in meters $(m)$.

\section{Estimation of Shoreline Change Rate Uncertainty at Individual Transects}

The uncertainty of a single transect's end-point shoreline change rate, $U_{R_{i}}$, is found as the quadrature addition of the uncertainties for each year's shoreline position, divided by the number of years between the shoreline surveys:

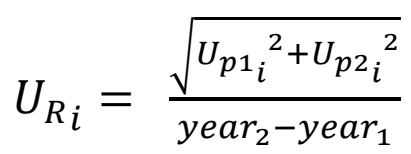

where $U_{p 1_{i}}$ and $U_{p 2}$ are the shoreline position uncertainties of the first (year ${ }_{1}$ ) and second (year $)^{\text {) }}$ shorelines, respectively, at transect $i$, determined in equation 1 (after Hapke and others, 2006).

For the linear regression method, the uncertainty of a single transect's shoreline change rate, $U_{R_{i}}$, is found here as the 90 percent confidence interval on the linear regression slope. Shoreline change rate uncertainties are included in the transect data files associated with this report (Gibbs and others, 2017).

\section{Regionally Averaged Rate Uncertainty}

In addition to shoreline change rates and rate uncertainties at individual transects, this report provides regionally averaged rates and the associated average rate uncertainty as a measure of broader scale trends (table 5).

Following the approach of Ruggiero and others (2013), the procedure for finding the uncertainty associated with regionally averaged shoreline change rates, $\bar{U}_{R q^{*}}$, described below, is 
the same for both the end-point and linear regression methods. We estimate that each transect rate uncertainty is partially independent of the others. To estimate the regionally averaged uncertainty of partially independent transect rates, we first evaluated the effective number of independent uncertainty values, $n^{*}$. Following Garrett and Toulany (1981), we found $n^{*}$ on the basis of the spatially lagged autocorrelation of each measure of shoreline change rate uncertainty. Assuming that the uncertainty of a region can be represented by $\bar{U}_{R}$, we found the uncertainty of a regionally averaged change rate to be:

$$
\bar{U}_{R q^{*}}=\frac{1}{\sqrt{n} *} \bar{U}_{R}
$$

In all regions, this method resulted in a large reduction in the original sample size, $\mathrm{n}$, shown in table 5 . The reduced effective sample size $\left(n^{*}\right)$ was also determined for combined regions and shoreline types by summing the $n^{*}$ values within each region. Average uncertainty values found using equation 3 , reported in table 5, are generally much smaller than the arithmetic mean confidence interval. 
Table 5. Summary of average shoreline change rates, average rate uncertainties, and percentage of transects eroding for the study area and each region relative to shoreline type.

[Uncertainty numbers in bold are confidence interval values that are less than the average rate, indicating the rates are statistically significant; LT, long-term rates, 1940s to 2010s; ST, short-term rates, $1980 \mathrm{~s}$ to $2010 \mathrm{~s} ; \mathrm{m} / \mathrm{yr}$, meters per year; m, meters]

\begin{tabular}{|c|c|c|c|c|c|c|c|c|c|c|}
\hline \multirow{2}{*}{ Shoreline type } & \multirow{2}{*}{$\begin{array}{l}\text { Number } \\
\text { of } \\
\text { transects } \\
(n)\end{array}$} & \multirow{2}{*}{$\begin{array}{c}\text { Independent } \\
n\left(n^{*}\right)\end{array}$} & \multirow{2}{*}{$\begin{array}{c}\text { Average } \\
\text { of rates } \\
(\mathrm{m} / \mathrm{yr})\end{array}$} & \multirow{2}{*}{$\begin{array}{c}\text { Average } \\
\text { uncertainty } \\
\text { (m/yr) }\end{array}$} & \multirow{2}{*}{$\begin{array}{c}\text { Uncertainty } \\
\text { reduced for } \\
n^{*}(\mathrm{~m} / \mathrm{yr})\end{array}$} & \multicolumn{2}{|c|}{ Maximum rate (m/yr) } & \multicolumn{3}{|c|}{ Percent of transects eroding } \\
\hline & & & & & & Erosion & Accretion & TOTAL & $\begin{array}{c}\text { More } \\
\text { than } 1 \\
\mathrm{~m} / \mathrm{yr}\end{array}$ & $\begin{array}{c}\text { More } \\
\text { than 3 } \\
\text { m/yr }\end{array}$ \\
\hline All transects, $\mathrm{LT}$ & 25,626 & 1220 & -1.4 & 1.4 & 0.04 & -21.7 & 10.6 & 84 & 35 & 14 \\
\hline All transects, ST & 25,613 & 6397 & -1.4 & 2.7 & 0.03 & -25.1 & 20.6 & 77 & 34 & 17 \\
\hline Beaufort Sea coast, LT & 18,500 & 994 & -1.8 & 1.3 & 0.04 & -21.7 & 10.6 & 88 & 44 & 19 \\
\hline Beaufort Sea coast, ST & 18,447 & 923 & -1.9 & 3.5 & 0.06 & -25.1 & 20.6 & 82 & 44 & 23 \\
\hline Chukchi Sea coast, LT & 7,126 & 226 & -0.3 & 1.5 & 0.01 & -4.6 & 8.3 & 74 & 10 & 1 \\
\hline Chukchi Sea coast, ST & 7,166 & 5474 & -0.1 & 0.8 & $\mathbf{0 . 0 0}$ & -8.3 & 13.0 & 66 & 8 & 1 \\
\hline All sheltered shorelines, LT & 10,862 & 950 & -0.9 & 0.6 & 0.07 & -15.7 & 7.4 & 89 & 27 & 6 \\
\hline All sheltered shorelines, ST & 10,796 & 685 & -1.0 & 1.3 & 0.20 & -25.1 & 9.6 & 85 & 27 & 8 \\
\hline All exposed shorelines, LT & 14,764 & 270 & -1.7 & 1.9 & 0.27 & -21.7 & 10.6 & 81 & 41 & 20 \\
\hline All exposed shorelines, ST & 14,817 & 435 & -1.8 & 3.8 & 0.50 & -24.4 & 20.6 & 72 & 39 & 24 \\
\hline All mainland shorelines, LT & 18,285 & 937 & -1.3 & 0.9 & 0.05 & -19.0 & 7.4 & 88 & 31 & 11 \\
\hline All mainland shorelines, ST & 18,025 & 741 & -1.5 & 2.0 & 0.13 & -25.1 & 12.6 & 83 & 32 & 15 \\
\hline Only exposed mainland, LT & 7,423 & 155 & -2.0 & 1.2 & 0.17 & -19.0 & 6.5 & 87 & 36 & 19 \\
\hline Only exposed mainland, ST & 7,229 & 181 & -2.3 & 3.1 & 0.31 & -24.4 & 12.6 & 81 & 39 & 25 \\
\hline Only exposed barrier, LT & 7,176 & 201 & -1.6 & 2.6 & 0.73 & -21.7 & 10.6 & 73 & 45 & 21 \\
\hline Only exposed barrier, ST & 7,423 & 212 & -1.3 & 4.5 & 1.81 & -22.5 & 20.6 & 63 & 39 & 23 \\
\hline \multicolumn{11}{|c|}{ REGION 1: U.S.-Canadian border to Hulahula River } \\
\hline All Transects, LT & 4,861 & 208 & -0.9 & 1.0 & 0.02 & -14.8 & 10.6 & 83 & 29 & 8 \\
\hline All Transects, ST & 4,964 & 215 & -0.9 & 2.8 & 0.04 & -19.6 & 11.2 & 76 & 29 & 10 \\
\hline Exposed shorelines, LT & 2,379 & 43 & -1.3 & 1.5 & 0.23 & -14.8 & 10.6 & 77 & 47 & 15 \\
\hline Exposed shorelines, ST & 2,471 & 75 & -1.3 & 4.6 & 0.54 & -19.6 & 11.2 & 67 & 46 & 19 \\
\hline Sheltered shorelines, LT & 2,482 & 165 & -0.5 & 0.4 & 0.03 & -4.4 & 1.6 & 89 & 13 & 0 \\
\hline Sheltered shorelines, ST & 2,493 & 140 & -0.5 & 0.9 & 0.08 & -4.6 & 2.3 & 84 & 13 & 0 \\
\hline
\end{tabular}




\begin{tabular}{|c|c|c|c|c|c|c|c|c|c|c|}
\hline \multirow{2}{*}{ Shoreline type } & \multirow{2}{*}{$\begin{array}{l}\text { Number } \\
\text { of } \\
\text { transects } \\
(n)\end{array}$} & \multirow{2}{*}{$\begin{array}{c}\text { Independent } \\
n\left(n^{*}\right)\end{array}$} & \multirow{2}{*}{$\begin{array}{c}\text { Average } \\
\text { of rates } \\
(\mathrm{m} / \mathrm{yr})\end{array}$} & \multirow{2}{*}{$\begin{array}{c}\text { Average } \\
\text { uncertainty } \\
\text { (m/yr) }\end{array}$} & \multirow{2}{*}{$\begin{array}{l}\text { Uncertainty } \\
\text { reduced for } \\
n^{*}(\mathrm{~m} / \mathrm{yr})\end{array}$} & \multicolumn{2}{|c|}{ Maximum rate (m/yr) } & \multicolumn{3}{|c|}{ Percent of transects eroding } \\
\hline & & & & & & Erosion & Accretion & TOTAL & $\begin{array}{c}\text { More } \\
\text { than } 1 \\
\mathrm{~m} / \mathrm{yr} \\
\end{array}$ & $\begin{array}{c}\text { More } \\
\text { than } 3 \\
\text { m/yr }\end{array}$ \\
\hline \multicolumn{11}{|c|}{ REGION 2: Hulahula River to Staines River } \\
\hline All Transects, LT & 1,994 & 170 & -0.9 & 0.6 & 0.02 & -6.8 & 2.1 & 88 & 26 & 9 \\
\hline All Transects, ST & 2,033 & 172 & -0.9 & 1.6 & 0.04 & -6.8 & 6.9 & 80 & 28 & 12 \\
\hline Exposed shorelines, LT & 1,114 & 11 & -1.3 & 0.8 & 0.25 & -6.8 & 2.1 & 87 & 39 & 15 \\
\hline Exposed shorelines, ST & 1,187 & 25 & -1.2 & 2.2 & 0.43 & -6.8 & 6.9 & 79 & 39 & 20 \\
\hline Sheltered shorelines, LT & 880 & 159 & -0.4 & 0.3 & 0.03 & -2.2 & 1.9 & 88 & 8 & 0 \\
\hline Sheltered shorelines, ST & 846 & 147 & -0.4 & 0.9 & $\mathbf{0 . 0 7}$ & -2.9 & 3.3 & 82 & 11 & 0 \\
\hline \multicolumn{11}{|c|}{ REGION 3: Staines River to Sagavanirktok River } \\
\hline All Transects, LT & 2,063 & 337 & -1.4 & 1.8 & 0.04 & -21.7 & 8.7 & 89 & 39 & 15 \\
\hline All Transects, ST & 1,933 & 313 & -1.0 & 3.5 & 0.18 & -13.6 & 20.6 & 79 & 34 & 17 \\
\hline Exposed shorelines, LT & 592 & 43 & -2.9 & 4.8 & 0.73 & -21.7 & 8.7 & 81 & 68 & 44 \\
\hline Exposed shorelines, ST & 516 & 11 & -2.0 & 10.0 & 3.09 & -13.6 & 20.6 & 73 & 63 & 50 \\
\hline Sheltered shorelines, LT & 1471 & 294 & -0.8 & 0.6 & 0.03 & -5.8 & 2.6 & 93 & 27 & 3 \\
\hline Sheltered shorelines, ST & 1417 & 302 & -0.7 & 1.2 & $\mathbf{0 . 0 7}$ & -11.0 & 5.8 & 80 & 23 & 5 \\
\hline \multicolumn{11}{|c|}{ REGION 4: Sagavanirktok River to Colville River } \\
\hline All Transects, LT & 2,887 & 144 & -1.1 & 1.2 & 0.04 & -12.5 & 6.7 & 85 & 35 & 10 \\
\hline All Transects, ST & 2,820 & 74 & -1.0 & 2.4 & 0.11 & -18.7 & 19.6 & 79 & 36 & 10 \\
\hline Exposed shorelines, LT & 1,002 & 33 & -1.6 & 2.6 & 0.45 & -12.5 & 6.7 & 65 & 45 & 27 \\
\hline Exposed shorelines, ST & 934 & 51 & -1.0 & 5.2 & 0.72 & -18.7 & 19.6 & 55 & 37 & 26 \\
\hline Sheltered shorelines, LT & 1,885 & 111 & -0.8 & 0.4 & 0.04 & -3.9 & 1.4 & 95 & 30 & 1 \\
\hline Sheltered shorelines, ST & 1,886 & 23 & -0.9 & 1.0 & 0.21 & -6.0 & 5.1 & 91 & 36 & 2 \\
\hline \multicolumn{11}{|c|}{ REGION 5: Colville River to Cape Halkett } \\
\hline All transects (exposed), LT & 1,958 & 17 & -1.1 & 0.7 & 0.16 & -9.1 & 5.7 & 93 & 40 & 12 \\
\hline All transects (exposed), ST & 1,550 & 17 & -1.3 & 1.8 & 0.44 & -10.8 & 12.6 & 90 & 36 & 19 \\
\hline \multicolumn{11}{|c|}{ REGION 6: Cape Halkett to Ikpikpuk River Delta } \\
\hline All Transects, LT & 1,864 & 14 & -5.9 & 3.0 & 0.67 & -19.0 & 7.4 & 92 & 79 & 62 \\
\hline All Transects, ST & 1,900 & 24 & -7.1 & 8.4 & 1.00 & -24.4 & 9.6 & 93 & 82 & 67 \\
\hline Exposed shorelines, LT & 1,676 & 11 & -6.4 & 3.0 & 0.92 & -19.0 & 6.5 & 95 & 82 & 66 \\
\hline
\end{tabular}




\begin{tabular}{|c|c|c|c|c|c|c|c|c|c|c|}
\hline \multirow{2}{*}{ Shoreline type } & \multirow{2}{*}{$\begin{array}{l}\text { Number } \\
\text { of } \\
\text { transects } \\
(n)\end{array}$} & \multirow{2}{*}{$\begin{array}{l}\text { Independent } \\
n\left(n^{*}\right)\end{array}$} & \multirow{2}{*}{$\begin{array}{c}\text { Average } \\
\text { of rates } \\
(\mathrm{m} / \mathrm{yr})\end{array}$} & \multirow{2}{*}{$\begin{array}{c}\text { Average } \\
\text { uncertainty } \\
\text { (m/yr) }\end{array}$} & \multirow{2}{*}{$\begin{array}{l}\text { Uncertainty } \\
\text { reduced for } \\
n^{*}(\mathrm{~m} / \mathrm{yr})\end{array}$} & \multicolumn{2}{|c|}{ Maximum rate (m/yr) } & \multicolumn{3}{|c|}{ Percent of transects eroding } \\
\hline & & & & & & Erosion & Accretion & TOTAL & $\begin{array}{c}\text { More } \\
\text { than } 1 \\
\text { m/yr }\end{array}$ & $\begin{array}{c}\text { More } \\
\text { than } 3 \\
\mathrm{~m} / \mathrm{yr}\end{array}$ \\
\hline Exposed shorelines, ST & 1,709 & 18 & -7.6 & 8.5 & 2.00 & -24.4 & 5.5 & 94 & 85 & 71 \\
\hline Sheltered shorelines, LT & 188 & 3 & -0.9 & 2.6 & 1.60 & -6.6 & 7.4 & 68 & 51 & 27 \\
\hline Sheltered shorelines, ST & 191 & 6 & -2.4 & 7.0 & 2.88 & -19.4 & 9.6 & 84 & 60 & 36 \\
\hline \multicolumn{11}{|c|}{ REGION 7: Smith Bay to Dease Inlet } \\
\hline All Transects, LT & 760 & 52 & -3.2 & 1.8 & 0.09 & -15.7 & 2.6 & 94 & 81 & 52 \\
\hline All Transects, ST & 981 & 75 & -3.7 & 5.3 & 0.18 & -25.1 & 9.3 & 91 & 82 & 61 \\
\hline Exposed shorelines, LT & 492 & 25 & -2.6 & 1.9 & 0.38 & -5.0 & 2.6 & 93 & 80 & 46 \\
\hline Exposed shorelines, ST & 713 & 44 & -3.0 & 5.9 & 0.89 & -7.8 & 9.3 & 89 & 82 & 57 \\
\hline Sheltered shorelines, LT & 268 & 27 & -4.3 & 1.5 & 0.28 & -15.7 & 0.5 & 96 & 81 & 64 \\
\hline Sheltered shorelines, ST & 268 & 31 & -5.4 & 3.6 & 0.65 & -25.1 & 0.1 & 98 & 84 & 69 \\
\hline \multicolumn{11}{|c|}{ REGION 8: Dease Inlet to Barrow } \\
\hline All Transects, LT & 2,113 & 52 & -2.5 & 1.6 & 0.14 & -13.7 & 6.4 & 91 & 74 & 28 \\
\hline All Transects, ST & 2,266 & 50 & -2.7 & 4.1 & 0.30 & -22.5 & 12.2 & 85 & 67 & 34 \\
\hline Exposed shorelines, LT & 733 & 12 & -3.0 & 3.1 & 0.89 & -13.7 & 6.4 & 83 & 70 & 37 \\
\hline Exposed shorelines, ST & 881 & 15 & -2.8 & 6.9 & 1.75 & -22.5 & 12.2 & 68 & 51 & 35 \\
\hline Sheltered shorelines, LT & 1,380 & 40 & -2.2 & 0.8 & 0.12 & -9.1 & 4.6 & 95 & 75 & 24 \\
\hline Sheltered shorelines, ST & 1,385 & 35 & -2.6 & 2.4 & 0.40 & -11.4 & 8.4 & 97 & 78 & 33 \\
\hline \multicolumn{11}{|c|}{ REGION 9: Barrow to Peard Bay } \\
\hline All transects (exposed), LT & 1,772 & 16 & -0.3 & 0.5 & 0.12 & -1.2 & 0.7 & 83 & 0 & 0 \\
\hline All transects (exposed), ST & 1,775 & 176 & -0.2 & 0.7 & 0.10 & -1.2 & 1.2 & 70 & 1 & 0 \\
\hline $\begin{array}{l}\text { Exposed shorelines, } \mathrm{ST} \\
\quad \text { (linear regression method) }\end{array}$ & 1,380 & 175 & -0.2 & 1.2 & 0.09 & -1.2 & 1.2 & 69 & 1 & 0 \\
\hline $\begin{array}{l}\text { Exposed shorelines, ST } \\
\text { (end-point method) }\end{array}$ & 395 & 1 & -0.3 & 0.7 & 0.67 & -1.2 & 0.6 & 75 & 2 & 0 \\
\hline \multicolumn{11}{|c|}{ REGION 10: Peard Bay to Icy Cape } \\
\hline All Transects, LT & 5,354 & 210 & -0.3 & 1.8 & 0.03 & -4.6 & 8.3 & 71 & 13.8 & 1.0 \\
\hline All Transects, ST & 5,391 & 4 & -0.1 & 0.7 & 0.60 & -8.3 & 13.0 & 64 & 9.7 & 2.0 \\
\hline Exposed shorelines, LT & 3,046 & 59 & -0.3 & 2.4 & 0.32 & -4.6 & 8.3 & 66 & 18.2 & 1.7 \\
\hline
\end{tabular}




\begin{tabular}{|c|c|c|c|c|c|c|c|c|c|c|}
\hline \multirow{2}{*}{ Shoreline type } & \multirow{2}{*}{$\begin{array}{l}\text { Number } \\
\text { of } \\
\text { transects } \\
(n)\end{array}$} & \multirow{2}{*}{$\begin{array}{l}\text { Independent } \\
\qquad n\left(n^{*}\right)\end{array}$} & \multirow{2}{*}{$\begin{array}{c}\text { Average } \\
\text { of rates } \\
(\mathrm{m} / \mathrm{yr})\end{array}$} & \multirow{2}{*}{$\begin{array}{c}\text { Average } \\
\text { uncertainty } \\
(\mathrm{m} / \mathrm{yr})\end{array}$} & \multirow{2}{*}{$\begin{array}{c}\text { Uncertainty } \\
\text { reduced for } \\
n^{*}(\mathrm{~m} / \mathrm{yr})\end{array}$} & \multicolumn{2}{|c|}{ Maximum rate (m/yr) } & \multicolumn{3}{|c|}{ Percent of transects eroding } \\
\hline & & & & & & Erosion & Accretion & TOTAL & $\begin{array}{c}\text { More } \\
\text { than } 1 \\
\mathrm{~m} / \mathrm{yr}\end{array}$ & $\begin{array}{c}\text { More } \\
\text { than 3 } \\
\text { m/yr }\end{array}$ \\
\hline $\begin{array}{l}\text { Exposed shorelines, ST } \\
\text { (end-point method) }\end{array}$ & 3,081 & 3 & 0.0 & 0.7 & 0.43 & -8.3 & 13.0 & 54 & 13.9 & 3.4 \\
\hline Sheltered shorelines, LT & 2,308 & 151 & -0.3 & 0.9 & 0.08 & -2.1 & 1.8 & 77 & 8.1 & 0.0 \\
\hline $\begin{array}{l}\text { Sheltered shorelines, ST } \\
\text { (end-point method) }\end{array}$ & 2,310 & 1 & -0.3 & 0.8 & 0.75 & -2.2 & 4.0 & 77 & 4.1 & 0.0 \\
\hline
\end{tabular}


Table 6. Long- and short-term maximum shoreline change rates for each region.

[All rates reported here were calculated using the linear regression method, except for Region 10 short-term rates, which were calculated using the end-point method. Max., maximum; $\mathrm{m} / \mathrm{yr}$, meters per year]

\begin{tabular}{|c|c|c|c|c|c|c|}
\hline Region & $\begin{array}{l}\text { Long-term } \\
\text { rate (m/yr) }\end{array}$ & $\underset{(\mathrm{m} / \mathrm{yr})}{ \pm}$ & Location & $\begin{array}{l}\text { Short-term } \\
\text { rate (m/yr) }\end{array}$ & $\underset{(\mathrm{m} / \mathrm{yr})}{ \pm}$ & Location \\
\hline \multicolumn{7}{|c|}{ REGION 1: U.S.-Canadian border to Hulahula River } \\
\hline Max. erosion & -14.8 & 7.5 & East Arey Island & -20.0 & 5.5 & East Arey Island \\
\hline Max. accretion & 10.6 & 1.6 & West Bernard Spit & 11.1 & 9.6 & West Bernard Spit \\
\hline \multicolumn{7}{|c|}{ REGION 2: Hulahula River to Staines River } \\
\hline Max. erosion & -6.8 & 8.1 & Barrier spit near Collinson Point & -6.8 & 8.0 & Barrier spit east of Brownlow Point \\
\hline Max. accretion & 2.1 & 3.6 & Barrier island east of Brownlow Point & 6.9 & 1.3 & Barrier island east of Brownlow Point \\
\hline \multicolumn{7}{|c|}{ REGION 3: Staines River to Sagavanirktok River } \\
\hline Max. erosion & -21.7 & 35.1 & McClure Islands & -13.6 & 45.3 & North Star Island \\
\hline Max. accretion & 8.7 & 11.3 & Duchess Island & 20.5 & 0.8 & Duchess Island \\
\hline \multicolumn{7}{|c|}{ REGION 4: Sagavanirktok River to Colville River } \\
\hline Max. erosion & -12.5 & 18.6 & Cross-Bartlett Island & -18.7 & 15.1 & Egg Island \\
\hline Max. accretion & 6.7 & 12.9 & Egg-Stump Island & 19.6 & 9.6 & Egg Island \\
\hline \multicolumn{7}{|c|}{ REGION 5: Colville River to Cape Halkett } \\
\hline Max. erosion & -9.1 & 3.6 & Western Harrison Bay north of Garry Creek & -10.8 & 19.9 & Western Harrison Bay north of Garry Creek \\
\hline Max. accretion & 5.7 & 7.8 & Western Harrison Bay north of Garry Creek & 12.6 & 9.3 & Western Harrison Bay north of Garry Creek \\
\hline \multicolumn{7}{|c|}{ REGION 6: Cape Halkett to Ikpikpuk River Delta } \\
\hline Max. erosion & -19.0 & 4.2 & Northwest of Cape Halkett & -24.4 & 6.7 & Between McLeod Point and Avatanak Bight \\
\hline Max. accretion & 7.4 & 10.8 & West Pogik Bay & 9.6 & 10.0 & West Pogik Bay \\
\hline \multicolumn{7}{|c|}{ REGION 7: Smith Bay to Dease Inlet } \\
\hline Max. erosion & -15.7 & 12.9 & South of Tangent Point & -25.1 & 47.2 & South of Tangent Point \\
\hline Max. accretion & 2.6 & 3.7 & Northwest of Cape Simpson & 9.3 & 15.1 & Cape Simpson \\
\hline \multicolumn{7}{|c|}{ REGION 8: Dease Inlet to Barrow } \\
\hline Max. erosion & -13.7 & 9.6 & Martin Island & -22.5 & 6.2 & Martin Island \\
\hline Max. accretion & 6.4 & 4.8 & Point Barrow & 12.2 & 46.2 & Martin Island \\
\hline
\end{tabular}




\begin{tabular}{|c|c|c|c|c|c|c|}
\hline Region & $\begin{array}{l}\text { Long-term } \\
\text { rate (m/yr) }\end{array}$ & $\underset{(\mathrm{m} / \mathrm{yr})}{ \pm}$ & Location & $\begin{array}{l}\text { Short-term } \\
\text { rate (m/yr) }\end{array}$ & $\underset{(\mathrm{m} / \mathrm{yr})}{ \pm}$ & Location \\
\hline \multicolumn{7}{|c|}{ REGION 9: Barrow to Peard Bay } \\
\hline Max. erosion & -1.2 & 1.2 & Southwest of Killi Creek & -1.2 & 0.5 & Nulavik \\
\hline Max. accretion & 0.7 & 0.1 & Midway between Walakpa and Nunavak Bays & 1.2 & 0.4 & Barrow east of Imikpuk Lake \\
\hline \multicolumn{7}{|c|}{ REGION 10: Peard Bay to Icy Cape } \\
\hline Max. erosion & -4.6 & 10.7 & Barrier island near Nokotlek Point & -8.3 & 0.8 & Barrier island near Nokotlek Point \\
\hline Max. accretion & 8.3 & 19.5 & Barrier island at Icy Cape Pass & 13.0 & 0.8 & Barrier island at Icy Cape Pass \\
\hline
\end{tabular}




\section{Results from Analysis of Historical Shoreline Change}

In order to maintain consistency with other National Assessment of Shoreline Change reports, the term erosion, as used in this study, indicates the measured landward movement or retreat of the shoreline. No distinction was made between physical erosion and land loss or shoreline retreat as a result of breaching of coastal lake shorelines or flooding of the coast due to sea-level rise and (or) land subsidence - in this context erosion and retreat are interchangeable. Accretion, as used in this study, indicates the measured seaward progradation of the shoreline and, particularly in case of barrier islands and spits, may also represent the migration alongshore of a landscape feature.

For the presentation of shoreline change rates, the north coast of Alaska was subdivided into 10 regions (fig. 1), which are based broadly on coastal geomorphology and orientation of the coast. Barter and Tigvariak Islands were analyzed separately and only their exposed open-ocean shorelines are included in the regional averages.

Regionally averaged rates of long-term shoreline change and the associated average values of rate uncertainty for the north coast of Alaska between the U.S.-Canadian border and Icy Cape are presented in table 5. Maximum erosion and accretion rates for individual regions are reported in table 6 . These are updates of values from the previously published report for the study region, in which the geomorphology and coastal characteristics are described in detail (Gibbs and Richmond, 2015; Gibbs and others, 2015). Nearly all region-averaged rates are statistically significant in this update, resulting in a more scientifically robust dataset.

The northern coast of Alaska between the U.S.-Canadian border is dominantly erosional, with 84 percent of the total transects showing shoreline retreat over the long term (1940s-2010s) and 77 percent in the short term (1980s-2010s), with mean rates of shoreline change of $-1.4 \pm 0.04$ and $-1.4 \pm 0.03$ meters per year $(\mathrm{m} / \mathrm{yr})$, for the long and short term, respectively. Change rates are considerably higher on the Beaufort Sea coast compared to the Chukchi Sea coast, averaging $1.8 \pm 0.04 \mathrm{~m} / \mathrm{yr}$ for the long term and $-1.9 \pm 0.06 \mathrm{~m} / \mathrm{yr}$ for the short term along the Beaufort Sea coast and $-0.3 \pm 0.01 \mathrm{~m} / \mathrm{yr}$ for the long term and $-0.1 \pm 0.00$ for the short term along the Chukchi Sea coast. Erosion and accretion rates at individual transects range from -21.7 to $+10.6 \mathrm{~m} / \mathrm{yr}$ for the long-term analysis period and -25.1 to $+20.6 \mathrm{~m} / \mathrm{yr}$ for the short-term analysis period.

The greatest average erosional rates for long- and short-term analysis periods, $-5.9 \pm 0.7$ and $-7.1 \pm 1.0 \mathrm{~m} / \mathrm{yr}$, respectively, were both measured in Region 6, between Cape Halkett and the Ikpikpuk River Delta. The smallest regionally averaged rates for the long- and short-term analysis periods, $-0.3 \pm 0.12$ and $-0.2 \pm 0.10 \mathrm{~m} / \mathrm{yr}$, respectively, were both measured in Region 9 between Barrow and Peard Bay.

Exposed mainland shorelines showed the highest average shoreline change rates over both the long term and short term $(-2.0 \pm 1.2$ and $-2.3 \pm 3.1 \mathrm{~m} / \mathrm{yr}$, respectively), compared to other shorelines. Sheltered shorelines showed relatively lower mean shoreline change rates over both the long term and short term $(-0.9 \pm 0.6$ and $-1.0 \pm 1.3 \mathrm{~m} / \mathrm{yr}$, respectively), compared to exposed ($1.7 \pm 0.3$ and $-1.8 \pm 0.5 \mathrm{~m} / \mathrm{yr}$, respectively) and barrier $(-1.6 \pm 0.7$ and $-1.3 \pm 1.8 \mathrm{~m} / \mathrm{yr}$, respectively) shorelines. Barrier shorelines include barrier islands, barrier spits, and barrier beaches. The maximum erosion rate $(-25.1 \pm 47.2 \mathrm{~m} / \mathrm{yr})$ measured in the study area for the short term, however, was measured along the sheltered coast of Region 3, just south of Tangent Point (table 6).

Mean erosion and accretion rates are larger in the short term relative to the long term for all shoreline types and regions (table 5). The maximum erosion and accretion rates on individual transects were also equal to or increased in the short-term compared to the long-term analysis 
periods at all locations, except for exposed eroding shorelines in Region 3, exposed accreting shorelines in Region 6, and sheltered accreting shorelines in Region 7 (table 5).

The percent of total transects eroding decreased in the short-term relative to the long-term analysis periods for nearly all shoreline types and regions, with the exception of combined and sheltered shoreline transects in Region 6 and sheltered shoreline transects in Region 7 and 10. The percent of transects eroding at greater than 1 and $3 \mathrm{~m} / \mathrm{yr}$ are presented in table 5 as an indicator of the relative magnitude of change throughout the study area. Nearly half the transects along the Beaufort Sea coast are eroding at a rate greater than $1 \mathrm{~m} / \mathrm{yr}$, compared to 10 percent or less of the transects along the Chukchi Sea coast. Along the Beaufort Sea coast, the percentage of transects eroding greater than 1 and $3 \mathrm{~m} / \mathrm{yr}$ is substantially higher between Cape Halkett and Point Barrow (Regions 6, 7, and 8), compared to the coast to the east.

\section{Summary}

The USGS updated calculations of long- and short-term rates of shoreline change for the north coast of Alaska between the U.S.-Canadian border and Icy Cape as part of the National Assessment of Shoreline Change Project. The updated calculations incorporate additional shoreline position data for locations where the original rates were calculated from only two shorelines.

The calculation of uncertainty associated with the long-term average rates has also been refined so as to be consistent with other National Assessment of Shoreline Change regional reports. As a result, the new average rates have less uncertainty than those presented in the original reports. Individual measurement transects for the north coast of Alaska between the U.S.-Canadian border and Icy Cape, as well as the other open-ocean shoreline regions along the U.S. coastline, can be viewed in the USGS Coastal Change Hazards Portal (http://marine.usgs.gov/coastalchangehazardsportal/).

\section{References Cited}

Fletcher, C.H., Romine, B.M., Genz, A.S., Barbee, M.M., Dyer, Matthew, Anderson, T.R., Lim, S.C., Vitousek, Sean, Bochicchio, Christopher, and Richmond, B.M., 2012, National assessment of shoreline change-Historical shoreline change in the Hawaiian Islands: U.S. Geological Survey Open-File Report 2011-1051, 55 p., https://pubs.usgs.gov/of/2011/1051.

Garrett, C.J.R., and Toulany, Bechara, 1981, Variability of the flow through the Strait of Belle Isle: Journal of Marine Research, v. 39, no. 1, p. 163-189.

Gibbs, A.E., Ohman, K.A., Coppersmith, R., and Richmond, B.M., 2017, A GIS compilation of updated vector shorelines and associated shoreline change data for the north coast of Alaska, U.S.-Canadian border to Icy Cape: U.S. Geological Survey data release, https://doi.org/10.5066/F72Z13N1.

Gibbs, A.E., Ohman, K.A., and Richmond, B.M., 2015, National assessment of shoreline change-A GIS compilation of vector shorelines and associated shoreline change data for the north coast of Alaska, U.S.-Canadian border to Icy Cape: U.S. Geological Survey Open-File Report 2015-1030, https://pubs.usgs.gov/of/2015/1030.

Gibbs, A.E., and Richmond, B.M., 2015, National assessment of shoreline change-Historical shoreline change along the north coast of Alaska, U.S.-Canadian border to Icy Cape: U.S. Geological Survey Open-File Report 2015-1048, 96 p., https://dx.doi.org/10.3133/ofr20151048. 
Hapke, C.J., Himmelstoss, E.A., Kratzmann, M.G., List, J., and Thieler, E.R., 2011, National assessment of shoreline change-Historical shoreline change along the New England and MidAtlantic coasts: U.S. Geological Survey Open-File Report 2010-1118, 57 p. https://pubs.usgs.gov/of/2010/1118.

Hapke, C.J., and Reid, David, 2007, National assessment of shoreline change, Part 4-Historical coastal cliff retreat along the California coast: U.S. Geological Survey Open-File Report 20071133, 51 p., https://pubs.usgs.gov/of/2007/1133.

Hapke, C.J., Reid, David, Richmond, B.M., Ruggiero, P., and List, J., 2006, National assessment of shoreline change Part 3-Historical shoreline change and associated coastal land loss along sandy shorelines of the California coast: U.S. Geological Survey Open-File Report 2006-1219, 72 p., https://pubs.usgs.gov/of/2006/1219.

Himmelstoss, E.A., Kratzmann, M.G., and Thieler, E.R., 2017, National assessment of shoreline change-Summary statistics for updated vector shorelines and associated shoreline change data for the Gulf of Mexico and Southeast Atlantic coasts: U.S. Geological Survey Open-File Report 2017-1015, 8 p., https://doi.org/10.3133/ofr20171015.

Morton, R.A., 1996, Geoindicators of coastal wetlands and shorelines, in Berger, A.R., and Iams, W.J., eds., Geoindicators-Assessing rapid environmental change in Earth systems:

Rotterdam, Netherlands, Balkema, p. 207-230.

Morton, R.A., and Miller, T.L., 2005, National assessment of shoreline change_-Part 2 Historical shoreline changes and associated coastal land loss along the U.S. Southeast Atlantic coast: U.S. Geological Survey Open-File Report 2005-1401, 35 p., https://pubs.usgs.gov/of/2005/1401.

Morton, R.A., Miller, T.L., and Moore, L.J., 2004, National assessment of shoreline change Part 1 - Historical shoreline changes and associated coastal land loss along the U.S. Gulf of Mexico: U.S. Geological Survey Open-File Report 2004-1043, 45 p., https://pubs.usgs.gov/of/2004/1043.

National Oceanic and Atmospheric Administration [NOAA], 2016, Tides and currents9497645 Prudhoe Bay, AK: National Oceanic and Atmospheric Administration web site, accessed October 18, 2016, at http://tidesandcurrents.noaa.gov/stationhome.html?id=9497645.

Ruggiero, Peter, Kratzmann, M.G., Himmelstoss, E.A., Reid, David, Allan, John, and Kaminsky, George, 2013, National assessment of shoreline change-Historical shoreline change along the Pacific Northwest coast: U.S. Geological Survey Open-File Report 2012-1007, 61 p., https://pubs.usgs.gov/of/2012/1007.

Taylor, J.R., 1997. An introduction to error analysis - The study of uncertainties in physical measurement: Sausalito, Calif., University Science Books, 327 p.

Thieler, E.R., Himmelstoss, E.A., Zichichi, J.L., and Ergul, A., 2009, The Digital Shoreline Analysis System (DSAS) version 4.0-An ArcGISTM extension for calculating shoreline change (ver. 4.3.4730, April 2012): U.S. Geological Survey Open-File Report 2008-1278, https://woodshole.er.usgs.gov/project-pages/DSAS/version4. 
ISSN 2331-1258 (online)

https://doi.org/10.3133/

ofr20171107 